\title{
EDITORIAL
}

\section{Choices: peripheral blood or marrow: natural or cloned yeasts}

(c) The Author(s), under exclusive licence to Springer Nature Limited 2022

Bone Marrow Transplantation (2022) 57:524-525;

https://doi.org/10.1038/s41409-022-01568-y

Choices are the hinges of destiny. Pythagoras. Ionian Greek Philosopher. Fig. 1. (570 BC-495 BC).

In the early days of Haemopoietic Cell Transplantation (HCT), in the late1970s, bone marrow was the tissue used as a source of haemopoietic stem cells. When Donnall Thomas and colleagues wrote their seminal papers for the New England Journal of Medicine showing that HCT could cure leukaemia [1, 2], they used bone marrow exclusively. In 1989 Gluckman and Broxmeyer [3] successfully used umbilical cord blood for HCT and in 2001 Bensinger [4] and colleagues demonstrated, in a randomised controlled trial, that G-CSF mobilised peripheral blood was as successful in the allogeneic setting as a source of haemopoietic stem cells as bone marrow. They concluded that: 'In patients given high-dose chemotherapy, with or without radiation, for the treatment of hematologic cancer, allogeneic peripheral-blood cells used for hematopoietic rescue restore blood counts faster than allogeneic bone marrow, without increasing the risk of graft-versushost disease'. So, today we have a number of choices in the use of haemopoietic tissue for HCT [5]. The procurement of the tissue of choice has different implications for both donor and recipient. To obtain bone marrow the donor receives a general anaesthetic; to obtain umbilical cord blood, a small volume may be inadequate and two cord blood samples may be required, and the use of mobilised peripheral blood requires that the donor is given recombinant (rh) G-CSF or other pharmaceutical interventions. All methods have their proponents; bone marrow harvest may lead to pelvic pain; mobilised peripheral blood may cause considerable bone pain in the donor and splenic rupture has been reported. Collection of umbilical cord blood may contribute to anaemia in the baby. Most importantly mobilised peripheral blood is associated with an increase in chronic Graft versus Host Disease when transplantation is carried out for Severe Aplastic Anaemia [6] or Leukaemia. Whereas CGvHD may have a protective effect against leukaemia relapse (graft versus leukaemia effect) it has no benefit in benign conditions such as Severe Aplastic Anaemia.

In August 2021, Saultz and Nemecek [7], concluded that, in spite of the superiority of bone marrow as a source of haemopoietic progenitors, the use of mobilised blood continues to increase. The recent BMT CTN 1303 study demonstrated a preference again for marrow product. Despite these and other reports, most adult transplant centres are using peripheral blood grafts rather than marrow, presumably as a consequence of the current pandemic. Related donors of mobilised peripheral blood may experience some serious adverse effects especially if they are overweight [8]. It is interesting that in an era of so-called evidence-based medicine, doctors continue to ignore the evidence. As Professor Robert (Bob) Gale says (personal communication): 'One of my greatest fantasies is the belief my analyses might change the behaviour of people who hold strong beliefs for which there are no supporting data. Then comes the realization such people rarely read'.

Do wine makers have to make choices? Yes, they do. One is whether to use natural or cloned yeasts. We know that yeast + sugar = alcohol $+\mathrm{CO}_{2}$. The question is which yeast to use? This is a highly contested area. Those of us, who have sat at lectures in medical school, about the taxonomy of yeasts remain bewildered. However, it turns out that certain yeasts are very important yeast for winemakers.

Our old friend Van Leeuwenhoek (1632-1723), the recognised discoverer of the microscope also identified yeasts but it was Louis Pasteur (1822-1895), some years later, who worked out the biochemistry of alcohol production during fermentation. Although there is an abundance of yeasts in the vineyard and wine cellar, Saccharomyces Cerevisiae is the most important yeast in the fermentation of grapes Fig. 2. Pasteur was the first to show that these living organisms were responsible for the transformation of glucose into ethanol. He also discovered that lactic acid fermentation takes place due to bacteria, not yeast. Some winemakers use the Pied de Cuves to initiate fermentation. This means adding yeasts other than Saccharomyces, to the fermentation tank. The yeasts selected may influence the final taste and bouquet of the wine. Many wine makers believe that the use of natural yeasts give their wine a unique flavour and the use of cloned yeasts results in a certain 'sameness' among wines.

I have spoken to a number of wine makers in Tuscany and Barbara Widmer's (from La Brancaia) response is typical: 'The fermentation process is driven purely by the natural yeasts and the only external factor, controlled by the wine maker, is the temperature... Natural fermentation is very important because the result allows each wine to express its individual unique character'. Similarly, Leon Femfert from Nittardi says: 'We generally use natural yeasts...If fermentation gets stuck, we may add natural cloned yeasts such as Sangiovese selected clones'. None of the winemakers I spoke to use genetically engineered yeasts.

Another yeast, Brettanomyces/Dekka, from the Saccharomyces family, is highly controversial. Commonly referred to as 'Brett' it is ubiquitous in vineyards. A small amount in wine apparently gives a pleasant flavour but too much Brett can make a wine taste metallic or spoilt. This, of course, should not be confused with 'corked' wine, which is due to TCA [9]. The major by-products of Brettanomyces are volatile phenols, 4-ethylphenol (4-EP) Fig. 3 and 4-ethylguaiacol (4-EG) [10]. 4-EP gives wine a smell of sweaty saddles. Having done a little cross-country horse riding in my younger days, I'm not sure I want that smell when I open a bottle of wine! 4-EP is used as a surrogate for Brettanomyces. Apparently a little 4-EP is valued by beer drinkers and some makers of craft beers insist that 4-EP adds a special flavour to their product. The best way to prevent Brettanomyces in the cellar is meticulous cleanliness and perhaps dimethyl decarbonate (C4H6O5), an organic compound which inactivates it. Strains of Brettanomyces 


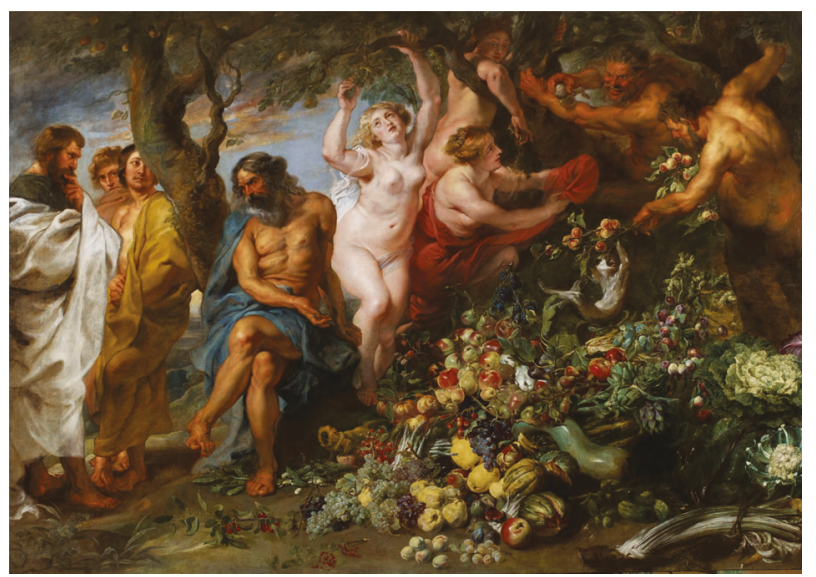

Fig. 1 Pythogoras. Pythogororas advocating vegetarianism. Peter Paul Rubens (1577-1640), Royal Collection, UK. Public domain.

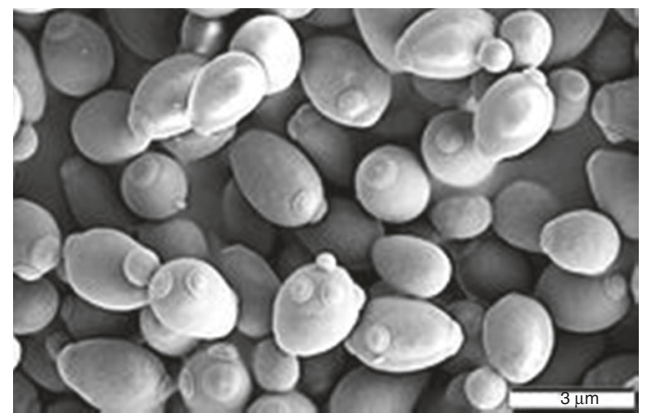

Fig. 2 Yeast commonly used in wine fermentation. Saccaromyces Cerevisiae, probably the most important yeast in fermentation of wine.
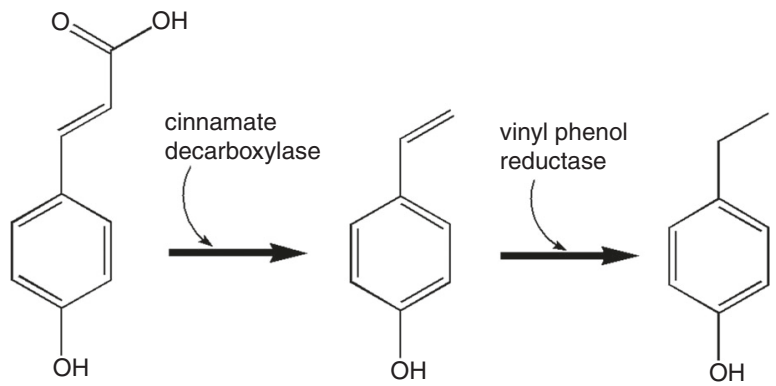

p-coumaric acid

4-vinylphenol

4-ethylphenol

Fig. 3 Brettanomyces. The conversion of p-coumaric acid to 4-ethylphenol (4-EP) by brettanomyces.

have a variable sensitivity to Sulphur Dioxide, used to preserve wine, by many wine makers [11].

So, whether you drink wine made with natural or cloned yeasts, remember that you are the final judge of what you enjoy.
Shaun R. McCann (D) $^{1 凶}$

'Bone Marrow Transplantation https://www.nature.com/bmt/. 凶email: shaunrmccann@gmail.com

\section{REFERENCES}

1. Thomas E, Storb R, Clift RA, Fefer A, Johnson FL, Neiman PE, et al. Bone-Marrow Transplantation (First of Two Parts). N Engl J Med. 1975;292:832-3. https://doi. org/10.1056/NEJM197504172921605.

2. Thomas ED, Storb R, Clift RA, Fefer A, Johnson L, Neiman PE, et al. Bone-Marrow Transplantation (Second of Two Parts). N Engl J Med. 1975;292:895-902. https:// doi.org/10.1056/NEJM197504242921706.

3. Gluckman E, Broxmeyer HE, Auerbach AD, Friedman HS, Douglas GW, Devergie A. et al. Hemopoietic Reconstitution in a Patient with Fanconi's Anemia by means of Umbilical Cord Blood from an HLA-identical Sibling. N Eng J Med. 1989;321:1174-8. https://doi.org/10.1056/NEJM198910263211707.

4. Bensinger WI, Martin PJ, Storer B, Clift R, Forman SJ, Negrin R, et al. Transplantation of Bone Marrow as compared with Peripheral-Blood cells from HLAidentical relatives in patients with Haematological Cancers. N Eng J Med. 2001:344:175-81. https://doi.org/10.1056/NEJM200101183440303.

5. Copelan EA, Chojecki A, Lazarus HM, Avalos BR. Allogeneic hematopoietic cell transplantation; the current renaissance. Blood Rev. 2019;34:34-44. https://doi. org/10.1016/j.blre.2018.11.001.

6. Schrezenmeier H, Passweg JR, Marsh JCW, Bacigalupo A, Bredeson CN, Bullorsky $\mathrm{E}$, et al. Worse outcome and more chronic GvHD with peripheral blood progenitor cells than bone marrow in HLA-identical sibling donor transplants in young patients with severe aplastic anemia. Blood. 2007;110:1397-400.

7. Saultz J, Nemecek E, Allogeneic Transplant: are we ignoring the data? ASH Clinical News. USA: ASH publications; 2021

8. Seftel MD, Chiptakdilhai P, Miller JP, Kobusingye $H$, Logan BR, Linenberger $M$, et al. Serious Adverse Events in Related Donors: A Report from the Related Donor Safe study. 2021. Transplant Cell Therap. https://doi.org/10.1016/j.jct.2021.01.009

9. McCann SR. Patients vary: so, do wines. February 2019. Bone Marrow Transplant. https://doi.org/10.1038/s41409-019-0477-5

10. Harding JEH, Harrup S. The Oxford Companion to Wine. P. 108, 4th Edition. Editor, Jancis Robinson. Oxford, UK: Oxford University Press; 2015.

11. McCann SR. Myths in wine and medicine. Bone Marrow Transplant. 2021. https:// doi.org/10.1038/s41409-021-01530-4.

\section{AUTHOR CONTRIBUTIONS}

This editorial was conceived and written entirely by SRMC.

\section{COMPETING INTERESTS}

The author declares no competing interests.

\section{ADDITIONAL INFORMATION}

Correspondence and requests for materials should be addressed to Shaun $R$. McCann.

Reprints and permission information is available at http://www.nature.com/ reprints

Publisher's note Springer Nature remains neutral with regard to jurisdictional claims in published maps and institutional affiliations. 